Jurnal Info Kesehatan

Vol. 19, No. 1, June 2021, pp. 20-27

P-ISSN 0216-504X, E-ISSN 2620-536X

DOI: 10.31965/infokes.Vol19Iss1.484

Journal homepage:http://jurnal.poltekeskupang.ac.id/index.php/infokes

RES E A R C H

Open Access

\title{
Factors Influencing Poor Postnatal Care in Sangihe Regency
}

\author{
Jelita Siska Herlina Hinonaung ${ }^{1 a^{*}}$, Astri Juwita Mahihody ${ }^{1 \mathrm{~b}}$, Grace Angel Wuaten ${ }^{1 \mathrm{c}}$ \\ ${ }^{1}$ Program Study of Nursing, Department of Health, Politeknik Negeri Nusa Utara, Sangihe, \\ North Sulawesi, Indonesia. \\ a Email address: siskahinonaung@gmail.com \\ b Email address: mahihodyastri@gmail.com \\ c Email address: gracewuaten@gmail.com
}

Received: 25 October 2020

Revised: 27 March 2021

Accepted: 26 May 2021

\begin{abstract}
Postpartum mothers from the first day of childbirth up to six weeks will undergo changes both physically and psychologically making intensive care indispensable. Conditions in which the postpartum mother does not get the correct and timely postnatal care lead to postpartum complications that can cause death. The objective of the study is to identify factors related to poor postnatal care in Sangihe Regency, North Sulawesi. This research was a correlation crosssectional study. The population was postpartum mothers in the working area of The Kuma Health Center of Sangihe Regency. In this study, researchers sampled 62 respondents. The variables included age, culture, mode of delivery, support, and knowledge. The relationship between age, culture, mode of delivery, support, and knowledge with poor postnatal care was measured less using the chi-square test. In contrast, the determinants of poor postnatal care were identified employing logistics regression. The results showed that factors influencing poor postnatal care were age, culture, mode of delivery, support, and knowledge. Mode of delivery was discovered as the most dominant variable influencing poor postnatal care. This research concluded that age, culture, mode of delivery, support and knowledge had a correlation with poor postnatal care, and the most dominant variable was the mode of delivery. Researcher hopes that these findings could help health workers and local governments to direct appropriate postpartum care, especially other postnatal care requiring further research.
\end{abstract}

Keywords: Factors, Influence, Postnatal Care.

*Corresponding Author:

Jelita Siska Herlina Hinonaung

Program Study of Nursing, Universitas Muhammadiyah Lamongan, East Jawa, Indonesia.

Email: s1skahınonaung@gmail.com

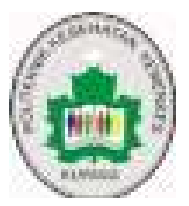

(C) The Author(s) 2021. This article is distributed under the terms of the Creative Commons Attribution 4.0 International License (http://creativecommons.org/licenses/by/4.0/), which permits unrestricted use, distribution, and reproduction in any medium, provided you give appropriate credit to the original author(s) and the source, provide a link to the Creative Commons license, and indicate if changes were made. The Creative Commons Public Domain Dedication waiver (http://creativecommons.org/publicdomain/zero/1.0/) applies to the data made available in this article, unless otherwise stated. 


\section{INTRODUCTION}

Postpartum mothers from the first day of childbirth up to six weeks undergo changes both physically and psychologically, which makes intensive care indispensable. Conditions in which the postpartum mother does not get the correct and timely postnatal care lead to postpartum complications that can cause death. According to WHO, every day in the world, Maternal Mortality Rate (MMR) reaches 830 cases of mothers dying from diseases/complications related to pregnancy and childbirth (WHO, 2018). In 2015, MMR in Indonesia reached 305 deaths per 100,000 live births, and every day, 38 mothers died (Archadi, 2019). Referring to the $3^{\text {rd }}$ Sustainable Development Goal (SDGs), the maternal mortality rate should be below 70 per 100,000 births (WHO, 2018). There were 71 cases for health profile of North Sulawesi province in 2015, while in the Sangihe Regency, there were 6 cases (Dinas Kesehatan Sulawesi Utara, 2017) and there was one case in the working area of the Kuma Health Center (Dinas Kesehatan Kepulauan Sangihe, 2017).

Various attempts have been conducted to reduce MMR. One of which was through outreach activities to residents related to postpartum care (Dinas Kesehatan Kepulauan Sangihe, 2017). Based on the results of the study completed at Srikaban Binjai Maternity House in 2016, it is revealed that 19 respondents (63.3\%) had sufficient knowledge on postpartum maternal, especially the basic needs during the postpartum period, 4 respondents $(13.3 \%)$ had good knowledge, while the other 7 respondents $(23.3 \%)$ had less knowledge (Seniorita, 2017). Various examples of postpartum treatment actions performed in miri Sragen sub-district are as follows; mothers should always bring objects (scissors, nail clippers, and pins) outdoors or indoors, they should sleep in a half-sitting position with straight feet for 40 days, they should consume nutrients by drinking herbal medicine, abstain from food consumption, as well as apply self-care by doing body massage (Yuliyanti, 2014). The results of the study revealed that knowledge, culture, and support are closely related to postpartum care (Yuliyanti, 2014); (Nurhabibi \& Rahayuningsih, 2018); (Rahayu, et. al., 2017); (Marmi, et. al., 2011).

The amount of research on postpartum care in Sangihe Regency is still relatively minimal. Based on observations made to one of the postpartum mothers in the Kuma area, it was discovered that postpartum mothers had performed postpartum care by consuming traditional herbal medicine and replacing their sanitary napkins when they were full. It indicates that mother has not made optimal efforts in implementing postnatal care. Nurhabibi \& Rahayuningsih, 2018 argued that suboptimal postpartum care may cause infections or complications which leads to death in postpartum mothers. Therefore, this study aims to identify factors related to poor postnatal care in Sangihe District.

\section{RESEARCH METHOD}

This study was quantitative research employing analytical survey research method. The design of this study used cross-sectional correlation studies. This study was conducted in the working area of Kuma Health Center in July 2019. The population of this study was postpartum mothers in the working area of Kuma Health Center. The sampling method was purposive sampling, with the following inclusion criteria: (1) postpartum mothers living in the working area of Kuma Health Center, (2) mothers who could read and write, and (3) mothers who were willing to be respondents. The 
exclusion criteria belong to mothers who had not been living in the working area of Kuma Health Center for less than a month. The total sample size was obtained by formula, as follow: $\mathrm{NZ}(1-\alpha / 2)^{2} \mathrm{P}(1-\mathrm{P}) / \mathrm{Nd} 2+\mathrm{Z}(1-\alpha / 2)^{2} \mathrm{P}(1-\mathrm{P})$ with $\mathrm{n}=$ sample size, $\mathrm{N}=$ population size a number $74, \mathrm{Z}(1-\alpha / 2) \quad=1.96, \mathrm{P}=\operatorname{proportion}(0.5), 1-\mathrm{P}=$ $0.5, d=$ desired level of precision (0.05) (Riyanto, 2019). The number of samples in this study was 62 respondents.

The instrument was in form of questionnaires. The knowledge-focused questionnaire consisted of 20 question items. This questionnaire was organized in the form of a statement with choices of "right or wrong" answers. As for the favorable statement, if the choice of answer was "correct", it would be given a value of 1, and if the choice of answer was "wrong," it would be given a value of 0 . Meanwhile, on the unfavorable statement, the choice of the answer "wrong" is given a value of 0 , and the choice of the answer is "correct", would be given a value of 1 . The knowledge assessment was categorized as good if the respondent met the score of $\geq 10$, while the respondent was categorized as having bad knowledge if it met the score of $<10$. Questionnaires regarding poor postnatal care consisted of 20 item questions. Poor postnatal care questionnaires were organized in the form of statements with the following choice of answers: "completely disagree", "disagree", "agree", or "strongly agree". The choice of a completely disagreed answer was given a value of 1 , the choice of a disapproval answer was given a value of 2, the choice of an agreed answer was given a value of 3 , and the choice of a strongly agreed answer was given a value of 4 . Assessment on postnatal care was categorized as poor if the respondent met the score of $\geq 40$, while postnatal care was categorized poor if respondent met the score of $<40$. Other variables such as maternal age, culture, mode of childbirth and support were measured using demographic questionnaires. Age was measured based on the respondents' number of years of birth calculated per year by age category $\leq 19$ years, $>19-35$ years, or $\geq 35$ years. Culture was assessed based on respondents' classification of ethnicity. Respondents were categorized using Sangihe culture when answering Sangihe tribe as an answer to questions about tribe, respondents were categorized using Minahasa culture as an answer to questions about ethnicity, apart from these options, respondents were categorized in the category of 'using other cultures'. Delivery mode was measured based on the classification of delivery actions performed by respondents. Delivery mode was categorized as vaginal delivery if childbirth was through the birth canal per vagina and caesarean section delivery if the delivery by sectio caesarean. Support was measured by family members who assisted respondents in performing postpartum care which were then divided into categories; husband, mother-in-law, mother, or friend.

The forms of data analysis used to include univariate, bivariate, and multivariate analysis. Univariate analysis aims to identify the distribution of data on all variables. The bivariate analysis aims to look at the relationship between independent and dependent variables using the chi-square test with a significance level of $p<0.05$. Multivariate analysis aims to identify which variables affect dependent variables the most. Variables analyzed in multivariate analysis, which are variables with a value of $p$ $<0.25$ in bivariate analysis. Multivariate analysis employed logistics regression analysis with stepwise reverse method with significance level $\alpha=$ confidence level 0.05 and $95 \%$. This research was approved by the Committee for The Ethics of Health Polytechnic of Manado, with the number: 01/08/041/2020. The researchers ensured that all respondents obtained proper information approval. 
Hinonaung, J. S. H., Mahihody, A. J., \& Wuaten, G. A. (2021). Factors Influencing Poor Postnatal Care in Sangihe Regency. JURNAL INFO KESEHATAN, 19(1), 20-27. https://doi.org/10.31965/infokes.Vol19/ss1.484

\section{RESULTS AND DISCUSSION}

Table 1. Bivariate analysis by age, culture, education, mode of delivery.

\begin{tabular}{|c|c|c|c|c|c|c|c|}
\hline \multirow{3}{*}{ Variable } & \multicolumn{4}{|c|}{ Poor postnatal Care } & \multirow{2}{*}{\multicolumn{2}{|c|}{ Total }} & \multirow{3}{*}{ p-value } \\
\hline & \multicolumn{2}{|c|}{ No } & \multicolumn{2}{|c|}{ Yes } & & & \\
\hline & $\mathbf{n}$ & $\%$ & n & $\%$ & $\mathbf{N}$ & $\%$ & \\
\hline \multicolumn{8}{|l|}{ Age } \\
\hline$<19$ years & 5 & 45.5 & 6 & 54.5 & 11 & 100 & $0.020 *$ \\
\hline$\geq 19-35$ years & 12 & 46.2 & 14 & 53.8 & 26 & 100 & \\
\hline$>35$ years & 3 & 12 & 22 & 88 & 25 & 100 & \\
\hline
\end{tabular}

\section{Culture}

\begin{tabular}{lrrrrrrr}
\hline Sangihe & 3 & 12.5 & 21 & 87.5 & 24 & 100 & $0.005^{*}$ \\
Minahasa & 4 & 26.7 & 11 & 73.3 & 15 & 100 & \\
Other & 13 & 56.5 & 10 & 43.5 & 23 & 100 & \\
\hline
\end{tabular}

Mode of delivery

\begin{tabular}{lrrrrrrr}
\hline Vaginal delivery & 9 & 60 & 6 & 40 & 15 & 100 & $0.008^{*}$ \\
Caesarea section & 11 & 23.4 & 36 & 76.6 & 47 & 100 & \\
delivery & & & & & & &
\end{tabular}

\section{Support}

\begin{tabular}{lrrrrrrr}
\hline Husband & 12 & 46.2 & 14 & 53.8 & 26 & 100 & 0.130 \\
Mother-in-law & 1 & 8.3 & 11 & 91.7 & 12 & 100 & \\
Mother & 5 & 31.3 & 11 & 68.7 & 16 & 100 & \\
Friend & 2 & 25 & 6 & 75 & 8 & 100 & \\
\hline
\end{tabular}

\section{Knowledge}

$\begin{array}{lrrrrrrr}\text { Poor } & 13 & 59 & 9 & 41 & 22 & 100 & 0.001^{*} \\ \text { Good } & 7 & 17.5 & 33 & 82.5 & 40 & 100 & \end{array}$

* Statistically significant $(p<0.05)$

Table 1 reveals that the variables significantly related to poor postnatal care are age with p-value of 0.020 , culture with p-value 0.005 , mode of delivery with $p$-value 0.008 , support with p-value 0.130 , and knowledge with p-value 0.001 . 
Table 2. Dominant factors influencing poor postnatal care using logistic regression test.

\begin{tabular}{|c|c|c|}
\hline Variable & $\begin{array}{r}\text { Model } 1 \\
\text { OR }(95 \% \text { CI })\end{array}$ & $\begin{array}{r}\text { Model 2 } \\
\text { OR }(95 \% \text { CI })\end{array}$ \\
\hline \multicolumn{3}{|l|}{ Mother's age } \\
\hline \multicolumn{3}{|l|}{$<19$ years } \\
\hline$\geq 19-35$ years & $0.124(0.009-1.783)$ & $0.259(0.033-2.027)$ \\
\hline$>35$ years & $0.372(0.047-2.922)$ & $0.350(0.60-2.051)$ \\
\hline \multicolumn{3}{|l|}{ Culture } \\
\hline \multicolumn{3}{|l|}{ Sangihe } \\
\hline Minahasa & $0.000(0.000)$ & \\
\hline Other & $0.000(0.000)$ & \\
\hline \multicolumn{3}{|l|}{ Mode of delivery } \\
\hline \multicolumn{3}{|l|}{ Vaginal delivery } \\
\hline Caesarea section delivery & $2.627(0.448-15.421)$ & $3.951(0.806-19.369)$ \\
\hline \multicolumn{3}{|l|}{ Support } \\
\hline \multicolumn{3}{|l|}{ Husband } \\
\hline Mother-in-law & $0.143(0.009-2.215)$ & $0.144(0.012-1.740)$ \\
\hline Mother & $0.330(0.007-15.024)$ & $0.361(0.013-10.225)$ \\
\hline Friend & $0.111(0.006-1.960)$ & $0.180(0.013-2.470)$ \\
\hline \multicolumn{3}{|l|}{ Knowledge } \\
\hline \multicolumn{3}{|l|}{ Poor } \\
\hline Good & $0.046(0.006-0.357)$ & $0.057(0.009-0.351)$ \\
\hline R Square & 0.560 & 0.478 \\
\hline$-2 \log$ likelihood & 46.221 & 52.013 \\
\hline
\end{tabular}

The results of the data analysis in table 2 reveal that age, culture, mode of delivery, support, and knowledge had a significant correlation with poor postnatal care. Model 2 was selected with higher R2 (0.478), lower -2log likelihood (52.013), and with a significant $95 \%$ confident interval. Logistic regression test discovered that the dominant variable influencing poor postnatal care was the mode of delivery (OR 3.951).It indicates that caesarean section had a probability of 3.951 times at poor postnatal care with vaginal delivery, with minimum risk of 0.806-19.369 times.

The results of this study present that the majority of respondents belong to the category of poor postnatal care. It was because respondents were still mistaken in answering questions about the benefits of taking vitamin A, doing pregnancy exercise, good contraception for postpartum mothers, the benefits of postpartum visitation, clinical symptoms of postpartum harmful signs, such as infection, bleeding, as well as problems in breastfeeding. The results of previous studies revealed that mothers who do not understand about postpartum care may increase the risk of maternal death during puerperal (Eldawati, 2015). One of the leading causes of maternal death is bleeding and postpartum infection (Archadi, 2019).

The lack of good postnatal care in this study was due to the fact that there were still respondents aged $<19$ years and $>35$ years who were at risk. Age affects the use of the mother to perform postpartum care (Tolera, et. al., 2020). The ideal age during the postpartum period is $\geq 19-35$ years (Kumalasari, et. al., 2020). Young mothers are considered less experienced in providing care during childbirth compared to mothers who are of age (Trisna, 2016).

The results reveal that there was a correlation between age factors and poor postnatal care. Mothers aged $>35$ are at risk of postnatal care 0.350 times higher than 
mothers aged $<19$. The results of previous studies also present that age was related to complications in childbirth. In the case of mothers with a risky age, they tend to possess a 2,203 times higher risk of childbirth complications than mothers without risk (Astutik, 2018). In line with the study of Tolera, et. al, (2020), it was discovered that maternal age factors were associated with non-utilization of puerperal care, in which the risk of experiencing postpartum care visits was 3.4 times higher than women aged 15-19 years.

The result of this study discovered that there is a correlation between knowledge and poor postnatal care. Previous research also revealed that age affected a person's level of knowledge. The majority of people in the study were in the adult category which meaning that they had been able to receive information. Kumalasari, (2020) stated that the higher a person's age, the easier they absorb information. The results of this study were also in line with previous research that discovered a correlation between the science possessed by postpartum mothers and postpartum care practices (Eldawati, 2015; Olajubu, et. al., 2019; Beraki, et. al., 2020). Good knowledge of postpartum mothers is influenced by their interests in following counseling from health workers on postpartum care (Seniorita, 2017).

The result of this study shows that there was a correlation between support factors in poor postnatal care respondents (postpartum mothers) who received support from their birth mothers which were 0.361 times more at risk of poor postnatal care than postpartum mothers who received support from their husbands. The results of previous research revealed that the presence of husband support contributes greatly to the tendency of postpartum depression (Amalia, et. al., 2019).

This study also discovered that there was a correlation between culture and postnatal care. The majority of respondents used Sangihe culture and some did other postnatal treatments such as Baraho and Bakera. Baraho was completed by burning coconut shells or wood until charcoal appears. Furthermore, the palm of the mother hand was used as a heat conductor from the coals to the body to warm up. It is intended to make the mother's body warm. There is no research on baraho's benefits for postpartum mothers.

Another postpartum treatment performed in Sangihe culture was Bakera. Bakera is another method of postpartum treatment by steam bathing employing traditional ingredients which have been passed down from generation to generation performed by the mother during the postpartum period. This traditional method was performed by people in North Sulawesi (Sampouw, 2015). Therapeutic effects of thermotherapy and aromatherapy contribute to the effectiveness of Bakera (Zumsteg \& Weckerle, 2007).

The multivariate analysis in this study revealed that the dominant variable affecting poor postnatal care was delivery mode. It explains that caesarean section delivery had a 3,951 probability of poor postnatal care with vaginal delivery, with a minimum risk of $0.806-19.369$ times. This discovery is in line with the research of Wardani, et. al., (2012), which explained that postpartum care for postpartum mothers had a significant relationship both in the treatment group with a value of $\mathrm{p} 0.015$ and in the control group with a value of $\mathrm{p}$ 0.017. Respondents who conducted a caesarean section but were not careful in postpartum efforts were those who did not eat food that accelerated wound healing and did not keep the wound dry and clean. There was a possibility in mothers who gave birth by caesarean section to experience a decrease in self-care efforts after childbirth. It happens because the patient's need for self-care outweighs the patient's ability to perform self-care.

The research instrument was written in Indonesian as the language of instruction so that respondents did not have difficulty in filling out the questionnaires. Furthermore, 
the content of the question was large enough to allow information bias in this study. This research provides information for postpartum mothers about the right care after childbirth.

\section{CONCLUSION}

Based on the results of the study, it can be concluded that the majority of postnatal care in Sangihe District was based on poor postnatal care. There is a significant correlation between age, culture, maternal labor, support, and poor level of knowledge of postnatal care. The dominant factor associated with poor postnatal care was delivery mode. These findings may help health officials and local governments to direct appropriate postpartum care, primarily other postnatal care requiring more research. Health workers need to reactivate the postpartum class in order for the mother's knowledge of postpartum care to increase.

\section{REFERENCES}

Amalia, A., Ramadhana, M., \& Faradiba, A. T. (2019). Peran Dukungan Suami Terhadap Kecenderungan Depresi Paska Melahirkan. Jurnal Psikogenesis, 7(1), 13-17. doi: https://doi.org/10.24854/jps.v7i1.872

Achadi, E. L. (2019). Kematian maternal dan neonatal di indonesia. Tangerang: Rapat Kerja Kesehatan Nasional Kementerian Kesehatan RI.

Astutik, W., Dasuki, D., \& Kurniawati, H. F. (2018). Factors Influencing Maternal Labor Complication In Kutai Kartanegara Region. Belitung Nursing Journal, 4(5), 510-517.doi: https://doi.org/10.33546/bnj.364

Beraki, G. G., Tesfamariam, E. H., Gebremichael, A., Yohannes, B., Haile, K., Tewelde, S., \& Goitom, S. (2020). Knowledge on postnatal care among postpartum mothers during discharge in maternity hospitals in Asmara: a crosssectional study. BMC pregnancy and childbirth,20(1), 1-10. doi: https://doi.org/10.1186/s12884-019-2694-8

Dinas Kesehatan Kepulauan Sangihe. (2017). Profil Kesehatan Kepulauan Sangihe Tahun 2017. Sangihe: Dinas Kesehatan Sangihe.

Dinas Kesehatan Sulawesi Utara. (2017). Profil Kesehatan Provinsi Sulawesi Utara Tahun 2017. Manado: Dinas Kesehatan Sulawesi Utara.

Eldawati, S. (2015). Hubungan Pengetahuan dan Sikap Ibu Nifas dengan Praktik Perawatan Masa Nifas Di Kecamatan Gunungpati Kota Semarang Bulan JanuariMaret 2015. Jurnal Kesehatan Masyarakat (Undip), 3(3), 228-237. Retrieved from https://ejournal3.undip.ac.id/index.php/jkm/article/view/12151

Kumalasari, D., Dewinataningtyas, C., \& Soyanita, E. (2020). The Influence Of Prenatal Class Participation Towards Maternal Behavior During Postnatal In Kediri District. Siklus: Journal Research Midwifery Politeknik Tegal, 9(1), 80-85. doi: http://dx.doi.org/10.30591/siklus.v9i1.1625

Marmi, S. A., Retno, M., \& Fatmawati, E. (2011). Asuhan Kebidanan Patologi. Yogyakarta: Pustaka Pelajar.

Nurhabibi, F., \& Rahayuningsih, F. B. (2019). Pengaruh Pendidikan Kesehatan Tentang Perawatan Nifas Dengan Metode Take And Give Dalam Meningkatka Pengetahuan. Proceeding of The URECOL, 152-166. 
Olajubu, A. O., Olowokere, A. E., Ogundipe, M. J., \& Olajubu, T. O. (2019). Predictors of Postnatal Care Services Utilization Among Women in Nigeria: A Facility-Based Study. Journal of Nursing Scholarship, 51(4), 408-416.doi: https://doi.org/10.1111/jnu.12473

Rahayu, I. S., Mudatsir, M., \& Hasballah, K. (2017). Faktor budaya dalam perawatan ibu nifas. Jurnal Ilmu Keperawatan, 5(1), 36-49.

Riyanto, A. (2019). Statistik Deksriptif Untuk Kesehatan. Yogyakarta: Nuha Medika.

Sampouw, N. L. (2015). Efektivitas Budaya Bakera Sebagai Media Pengetahuan Ibu Nifas Tentang ASI Eksklusif di Kota Bitung Provinsi Sulawesi Utara. JIKMU, 5(3), 202-209.

Seniorita, D., \& Ratna, S. (2017). Gambaran Pengetahuan Ibu Post Partum Tentang Kebutuhan Dasar Selama Masa Nifas Di Rumah Bersalin Srikaban Binjai Tahun 2016. Jurnal Ilmiah Kohesi, 1(1), 32-42.

Tolera, H., Gebre-Egziabher, T., \& Kloos, H. (2020). Risk factors for women's nonutilization of decentralized primary health care facilities for postnatal care in rural western Ethiopia. Therapeutic Advances in Reproductive Health, 14, 1-19. doi: https://doi.org/10.1177/2633494120928340

Trisna, A. (2016). Praktik Perawatan Masa Nifas Di Kecamatan Pecangaan Kabupaten Jepara Terkait Dengan Faktor Sosial Budaya. Skripsi . Surakarta: Program Studi Sarjana Keperawatan, Fakultas Ilmu Kesehatan, Universitas Muhammadiyah Surakarta.

Wardani, T. A.P., Nursalam, \& Has, E. M. M. (2012). Kemandirian Perawatan Ibu Post Sectio Caesarea Dengan Menggunakan Pendekatan Discharge Planning Berdasarkan Teori Self Care Orem. fundamental \& Management Nursing Journal, 1(1), 1-10. doi: http://dx.doi.org/10.20473/fmnj.v1i1.12126

WHO. (2018). Maternal Mortality. Geneva: World Health Organization. Retrieved from http://www.who.int/news-room/fact-sheets/detail/maternal-mortality

Yuliyanti, L. (2014). Gambaran Perawatan Ibu Nifas Di Wilayah Kecamatan Miri Sragen. Skripsi. Surakarta: Fakultas Ilmu Kesehatan, Universitas Muhammadiyah Surakarta. Retrieved from http://eprints.ums.ac.id/31094/

Zumsteg, I. S., \& Weckerle, C. S. (2007). Bakera, a herbal steam bath for postnatal care in Minahasa (Indonesia): Documentation of the plants used and assessment of the method. Journal of ethnopharmacology,111(3), 641-650. doi: https://doi.org/10.1016/j.jep.2007.01.016 